\title{
Progress Towards Resolving the Measurement Link Between ICT and Poverty Reduction
}

\author{
Julian May and Kathleen Diga
}

This chapter provides a review on the debate and latest literature around Information and Communication Technologies (ICTs) and its connection to poverty. The review first acknowledges the trend of global poverty, which today can be measured in a multitude of dimensions. This multidimensional poverty measurement approach has emerged within ICTs and Development (ICTD) research alongside a new contribution called "digital poverty". When looking at the empirical linkages between the concepts of poverty and ICTs, the literature reveals heterogeneity in the measurement choices as to who are the poor and whether the poor have ICTs across developing countries. Yet in various cases where the poor have ICTs, some are found to be sensitive to changes of price and see variability within equity of affordability. Furthermore, only few studies have been able to show causal inference to make the micro-level impact linkage between ICTs and poverty. In reviewing this literature, we provide some of the major themes, gaps, and recommendations towards improving the understanding of ICTD and poverty.

\section{Introduction}

In January 1961, the United Nations (UN) declared its first "decade of development", focusing on the increasing growth rate of aggregate national income in developing countries while recognising the need to provide some benefit to the

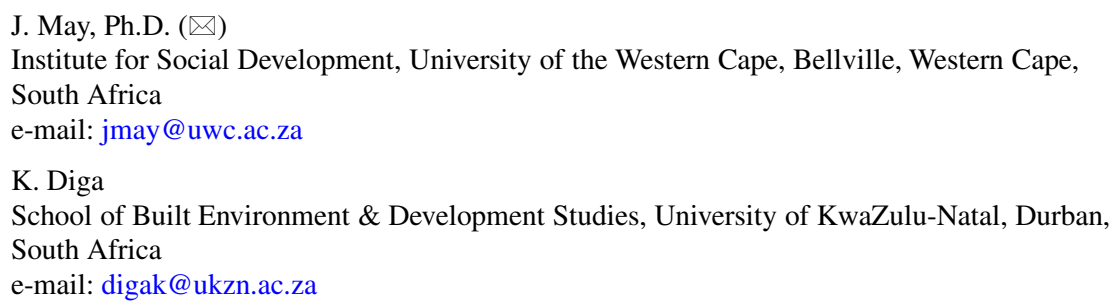


poorer sections of the population. Commenting on the poor record of this first decade of development in 1970, Robert McNamara, then president of the World Bank Group, argued for a " ... whole generation of development that will carry us to the end of the century" (cited in Meier 1970: p. 4). In the decade to follow, another World Bank President, Alden Clausen, stated that "... a key and central aim of the World Bank is the alleviation of poverty" (World Bank n.d.), while in 1980, 1990 and again in 2000 and 2001, "Poverty" was within the title of the World Development Reports (World Bank 1980, 1990, 2001). At the start of the fifth decade after President Kennedy's inaugural address, yet another World Bank President, James Wolfensohn, emphasised the need to " . . create an environment in which you can ... give opportunity and empowerment and recognition to people in poverty" (Wolfensohn 2000). Lending support to these statements, numerous international declarations have been made since the General Assembly's resolution 1710 (XVI) of 1996 committing most countries in the world to a range of laudable goals, all of which are appropriate if poverty is to be eliminated. Of these, the United Nations Millennium Declaration in 2000 and the commitment by 189 countries to the eight Millennium Development Goals (MDGs) were especially noteworthy. The expiry of the MDGs occurs in 2015, and current reflection is being made as to whether much has changed in the reduction of poverty since the first declaration over 50 years ago.

After over five decades of sentiments, there has been evidence of dramatic shifts in global poverty. The USD 1.25-a-day absolute poverty rate in 2012 was $19 \%$ (or 1.1 billion people) compared to the previously high rates of $43 \%$ in 1990 (Ravallion 2013). This lower rate of global poverty has been the result of dramatic decline in China's poverty levels as well as steeper poverty declines among other developing countries (Ravallion 2013). For some, however, lower global poverty rates are not sufficient. The ongoing and persistent levels of poverty must be addressed, yet it remains active within many regions of the world, especially in sub-Saharan Africa. The UN has committed to driving the rate of extreme poverty to $0 \%$ by 2030 (United Nations 2013). This ambitious goal of poverty eradication has been supported by ongoing global changes. This includes the mix of improved economic growth policies in developing countries, dramatic gains in human capital both in terms of health and education and the roll out of government social policies such as cash transfers.

Contestation however is widespread as to which policy strategy mix would effectively tackle poverty eradication. In a world shrouded with the global financial crisis and a wide variety of economic and social programmes, one can be left uncertain as to the most effective way forward for the end of the poverty. In India, researchers Drèze and Sen (2013) seek continual improvements of social welfare programmes to uplift the poor, while Bhagwati and Panagariya (2013) concentrate on market deregulation as the growth solution to end poverty. In such contexts, countries are left with decisions to develop their most appropriate policy combinations for future long-term growth (Rodrik 2013), using their evidencebuilding tools of measurement.

During this period, developing countries are also experiencing dramatically improved access and use of Information and Communication Technologies (ICTs). Among these policy decisions, one may ask to what degree should ICTs be considered within the development policy mix. While some argue uncertainty around the 
next industrial revolution after this latest growth of ICT innovation and services (Gordon 2012), others are more optimistic of the continuation of IT revolution (Byrne et al. 2013) and that the growth of ICTs within developing countries can continue unbounded in its potential economic prospects. The measure of ICT growth may well be a necessity as one may underestimate the ICT opportunities and policies which support inclusive growth for a national economy. In other words, the inclusion of ICTs as part of a country's inclusive growth policies may well provide another answer as to what factors can contribute towards the reduction of poverty.

The acknowledgement of ICTs as a contributing element in poverty reduction has not been instant. Much of the earlier 1990s, literature on ICTs focused on economic growth, acknowledging mainly descriptive results around gross domestic product (GDP) changes in relation to ICT growth (Röller and Waverman 2001; Teltscher and Korka 2005; Waverman et al. 2005). Furthermore, the efficiencies in industrial production via technological advancement leads to increased labour productivity or business-driven solutions and the way towards national economic growth (Oliner and Sichel 2000). While these studies have shown some evidence linking ICT to economic growth, such growth results may not necessarily be linked to poverty reduction. With that said, less emphasis was placed on the social analysis between people, structures and the ICTs within developing country communities and ICT's disruption to people's everyday life (Adeya 2002). Within this literature, we now have a poverty and ICTs literature baseline within ICTD research at a time when mobile phones were mainly held by the wealthy population due to high cost (Adeya 2002).

Since this initial ICT and poverty literature review, communication technology has rapidly become available across the globe. Citizens of various income levels and geographical regions have shown numerous cases of having some ICT access. What is less clear is the consistent choice of ICT measurement and poverty measures used by researchers when exploring the nexus between ICTs and poverty. Understanding the choices available and what has been used round measurements for ICTs and poverty are important in order to steer a common language particularly when working in a multidisciplinary area like ICTD. While there is a good base of literature which now covers ICTs and poverty (Spence and Smith 2009), this review particularly covers what research ground has been covered around ICTs and poverty measurement. Firstly, the literature brings readers up to date on the accepted multitude of approaches and indicators for measuring poverty. The section which follows further explores what ICTD researchers have used to measure poverty. Finally, the last section addresses the various indicators around ICTs which are being used in the poverty and ICT literature.

\section{Poverty Measure}

Before this chapter delves into the recent work around poverty and ICTs, we briefly look at the current trends around poverty and inequality research. There is a paucity of ICTD researchers who are experts in poverty research; it is thereby important to unpack the relevant tools and concepts around poverty measurement. In better 
understanding poverty measures, one can then choose the appropriate tool and thus understand its relationship to ICTs. Appropriate poverty measure would in future help government and institutions make evidence-based decisions around strategies of poverty reduction. Relevant poverty measurement highlighted here embraces three trends: the multiple dimensions of poverty, the ways in which one can build a composite index of poverty and the dynamic nature of poverty measured over time.

Hulme (2013) raises the point that positioning and conceptualisation are important ideas to consider if one wishes to understand poverty better. In this chapter, we take on Lipton's (1997) definition where poverty is "the inability to attain an objective and absolute minimum standard of living and that this can be reflected by a quantifiable indicator applied to a constant threshold that separates the poor from the non-poor" (found in May 2012a: p. 64). This measure of poverty is also inspired by Sen's (1999) human development approach whereby one can be deprived based on his or her capabilities to meet some set basic human needs. With this approach in mind, the conceptualisation of poverty measurement has been evolving, and preference is paid to measuring poverty beyond the sole indicator of income among individuals and households. As mentioned in the introduction, the absolute poverty rate has been on a decline. This global poverty line allows one to compare across countries. ${ }^{1}$ For example, in cross-country comparison, one interesting development to date is that the absolute poor (those living on USD 1.25 a day) are in majority located in middle-income countries (Sumner 2012). Besides this global poverty line, some countries measure their own relative income poverty line which assists to better serve the needs of their citizens. This relative poverty line usually consists of a cost for a basket of basic needs. A subjective poverty line where one determined deprivation by self-perception has been inspired by Bhutan's 'Happiness Index' and has gained global attention in poverty research.

Moving away from singular measures, there is much consensus among poverty researchers that poverty must be reviewed within a multidimensional lens (Alkire and Santos 2013; Moser 1998). Poverty is not only about one's level of income. Some of the recognised and important poverty dimensions besides financial include: human capital (including health and education levels), physical capital, welfare services (i.e. living standards levels) and social capital. The Human Development Index (HDI) has attempted to report on multiple social indicators (not necessarily poverty measures) and combine the indicators together to develop one index indicator which can compare low to very high human development across countries. At the micro household level, only recently have there been attempts to look at HDI among subgroups (Harttgen and Klasen 2012) and the further step to aggregate a country poverty index which brings multiple poverty elements together into one index measure (Alkire and Santos 2013).

Another evolution in poverty research is poverty dynamics. While yearly poverty and inequality statistics provide important cross-sectional baseline of populations, authors like Carter and Barrett (2006) have challenged these static models of poverty

\footnotetext{
${ }^{1}$ Taking into account that the quality of national statistics varies around the world.
} 
and moved towards monitoring poverty over time (chronic vs. transitory). Rather one can follow the same households over time (i.e. panel survey) and see whether these households transition in or out of poverty. The multiple dimensions of poverty measure and looking at poverty over time are relatively new phenomena in the empirical work of poverty researchers. These recent developments around poverty measurement are clearly improving the world's understanding of human deprivation through a more holistic manner. ICTD researchers who wish to examine populations in low-income communities and with poorer households would gain immensely in reflecting on these evolutions of poverty measurement.

There are various applied poverty reduction interventions such as improved education, health and cash transfers initiatives mixed with an ICT component, but this chapter is limited to describing each of these studies. Rather, the premise of this chapter instead is to concentrate on poverty measurement choices taken by these ICTD studies. As mentioned earlier, the measurement choices should help governments and institutions appropriately evaluate socio-economic improvements and thereby best inform evidence-based policy development.

\section{ICTs, Growth and Development}

The acceptance of these poverty measurement trends come at a time of ICT proliferation, more specifically one sees the abundant resources of affordable mobile phones and the ever accessible Internet which are effectively changing the way one communicates. These ICT tools have generated much interest in their ability to reach the hands of even the most poor, and this evidence has opened up heated debate on understanding whether poverty change and human development can be brought about with such tools (follow the expert discussion by Spence and Smith 2010; Toyama 2012). The optimistic see its availability to the poor as transformational in social relations and business functions, while others are less hopeful as they see little direct wellbeing changes of say reduction of hunger or better welfare facilities. ICT tools have generated much interest given their ability to demonstrate usage among the poor, and some studies do touch upon some of the new poverty dimensions such as concepts of empowerment, inclusion and connectedness in poor communities (see a rich list of literature in Baron and Gomez 2013). The next section unravels some of the ways deprivation is measured in ICTD research, along with how ICTs are measured.

The lower costs to mobile phone access in the early 2000s were seen in many developing countries. Mobile Internet and broadband infrastructure continues to reach across regions alongside a variety of Internet-enabled devices. The potential of using ICTs in creative ways to generate or access income and other assets by the least privileged has become more and more realistic. Resource-poor smart- or feature-phone owners could also participate and navigate through Internet social networking applications such as Facebook or Twitter. Moreover, the myriad of prepaid and micropayment service packages continue to expand usage at relatively 
lower costs than early 2000s. While the expansion of access and usage are becoming reality for developing country citizens, one is limited in understanding the actual levels of participation by the poor. Due to this limited knowledge, one is further uncertain of how close we are to the universal reach of ICTs. First, one must understand how ICTs and poverty are measured today in order to better determine a way forward to reach access for all, even to rural and poor members who can benefit from the improvements of communications infrastructure.

\section{Measuring ICTs in Developing Countries}

As following the guidance from poverty research, the theoretical use of Sen (1999) capability approach has dominated recent ICTD landscape. Utilising the human development approach, ICTs are explored theoretically as a broader and more holistic way to understand wellbeing as helping to expand the choices and freedoms of the actors themselves and their "functionings" or actions which in turn can lead to changes of wellbeing (Attwood et al. 2013). Further acceptance of multiple dimensions of poverty is seen in ICTD literature.

Data before 2007 was found to be sparse in providing accurate ICT usage information in datasets available such as in Africa (James and Versteeg 2007) and more so among the poor. The ICT statistics administered by International Telecommunications Union (ITU) have helped to portray global supply of ICT. Developing countries today are outweighing the growth of ICT uptake over developed countries (ITU 2012). The ITU also hosts the ICT Development Index (IDI) which ranks countries based on a composite number of ICT readiness, intensity and impact. The IDI includes countries classified on the United Nations' HDI ranking as "low" or "medium". Table 1 presents some of these aggregate ICT supply side indicators for some "low" to "medium" human development countries in Africa.

From this African region set, South Africa is leading in the ICT provision and HDI rank across indicators. The HDI ranks seem to also align with the sequence of the country's IDI rank. Furthermore, the other three African countries may have low HDI and IDI but now have over $50 \%$ of inhabitants with mobile phone subscriptions. Nevertheless one sees regional disparity of ICT access. In review of this global data, some "low" human development countries are experiencing high uptake in mobile phone subscriptions but low uptake of Internet usage (ITU 2011; Stork et al. 2013):

Technology is the tool, NOT the outcome. Judith Rodin (Rockefeller Foundation at the Social Good Summit, New York, September 2013)

While the ITU statistics may distinguish between HDI and IDI levels, they do not distinguish between rich and poor households or individuals within countries. Since 2007, much work has been done to rectify the paucity of available data and research around ICT usage by the poor and its role in poverty reduction. Descriptive micro-level ICT statistical research has been conducted in ICT access and usage by 


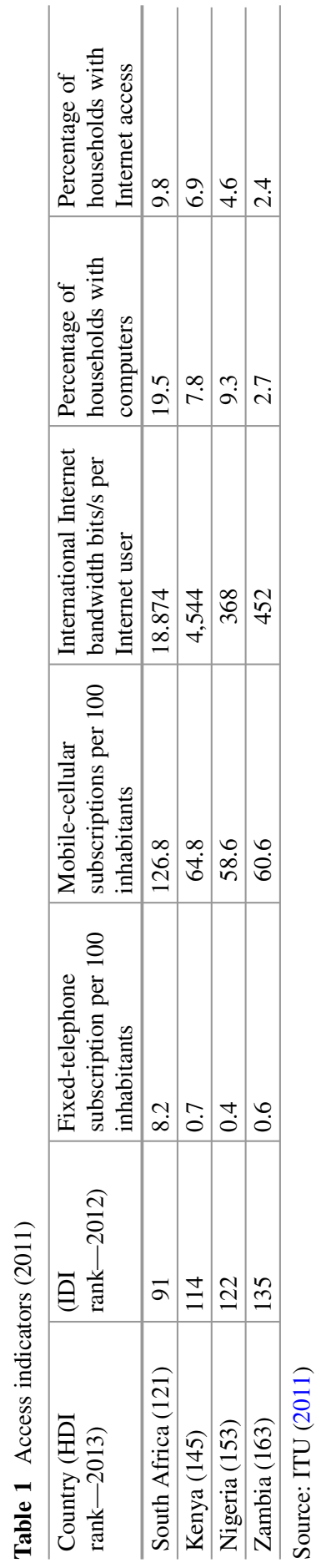


the poor (including this non-exhaustive list: Agüero et al. 2011; Barrantes 2007; de Silva and Zainudeen 2008; Galperin and Mariscal 2007; Gillwald and Stork 2008; May 2012c). Today we have some knowledge of actual demand for ICTs by the poor. This micro-level work starts with first finding how the poor are classified in ICTD studies and how many of these "poor" individuals and households have ICTs now available to them.

\section{Classification of Poor Within ICTD Studies}

When designing research involving poverty measures and ICTs, one must be upfront of the way in which these indicators will be done. The classification of "poor" without measurement is found in ICTD research, and reasons to not measure may be due to inconvenience and avoiding the need to ask uncomfortable questions about poverty to their respondents. This incomplete information does no justice for decision-makers or research in using findings towards social welfare improvements or resource allocations. The field of ICTD now has a wide range of measurement unit(s) of analysis choices when examining the poor, and therefore, there is no reason to not complete an appropriate measurement design for poverty.

At a country and community level, the "poor" enumerating areas or regions can be targeted, and households can fall in an area where the average household income is below some determined threshold. In some cases, a group of countries are assigned poor as a result of their cross-comparison rank definition of "low" based on GDP, GNP or their HDI (e.g. James n.d.). The result of James' (n.d.) study of 11 African countries shows that the relatively low GNP countries find households having stated more intensive usage (i.e. Ethiopia, Kenya and Uganda). Furthermore, intensive usage is also found among higher GNP countries for the reasons of communication for safety reasons (i.e. Botswana, Namibia and South Africa). In measuring among poor areas, shared ICT facilities can assist to fulfil underserved areas as was done in Yu'an, China for telecentres (Soriano 2007).

For individual and households, there is a variety of available ICTD statistical micro-level studies which attempt to classify the poor. ICTD studies have used income as a mechanism to measure the absolute poverty line (USD 1.25 or USD 2.00 per capita per day, such as May (2012c)) and relative poverty lines (expenditure per capita, Barrantes 2007, or national poverty data in South Africa, infodev 2012b). Other studies have chosen to measure the proportion of a subpopulation such as the lower $25 \%$ income bracket of the population (Gillwald and Stork 2008) or in other words, the bottom or base of the pyramid (de Silva and Zainudeen 2008; infodev 2012a, b). In following the multidimensional poverty research trend, a team of researchers in the project titled "poverty and ICTs in urban and rural eastern Africa" (PICTURE Africa) reviewed multiple dimensions of poverty through the lens of financial, human, physical, social and digital assets. What is found among these studies is that the poor are unlikely be a homogeneous group across regions given the variation of contexts. In ICTD research specifically, there is heterogeneity 
in the trend of choosing the measurement of the poor, and therefore, the choice of poverty threshold is just as broad as the multiple approaches to understand poverty itself.

\section{Defining Reach of ICT to the Poor: Access, Ownership and Usage Among the Poor}

While the choice of how to measure the "poor" among ICTD studies is heterogeneous, the classification of ICTs used by the poor has been just as wide ranging. The measurement of ICTs has included the count of physical products (i.e. radio, television, video recorders, computer, mobile phone, SIM cards, landline), those with connectivity (Internet connection-both mobile and fixed) and access to applications, services (e.g. email, Internet usage) and systems. In particular, there has been much progression in the thinking around three elements of ICTs and the poor: ICT access, ownership and usage at the community, household and individual level.

\section{ICT Access and Ownership of the Poor}

Predominantly, ICTD research has spent much time deriving ICT access indicators by asking poor households and individuals their level of access. ICT access from a micro-level demand survey has allowed for broad acceptance of access to include both private and shared access among household members (Rashid 2011). Public access computing (including telecentres and cybercafés) is deemed out of range for the poor (and also those with little to no education and the elderly) (Gomez 2013). Some of these access indicators have been gathered and provided by the government in order to support ICT infrastructure among poor communities, as well as to support their universal access policies.

Recently, ICT ownership or appropriation has been defined at the household or individual with low-income levels as part of a household's asset portfolio. For example, approximately three-quarters of those earning under South Africa's relative poverty line (USD 1.80 per person per day) have a mobile phone (infodev 2012b). Ownership across poor households in Latin America varied from high $90 \%$ ownership in Jamaica and Colombia to $30 \%$ access in Mexico in 2007 (Galperin and Mariscal 2007). Selected bottom of the pyramid households in Asia were monitored in 2006 for mobile phone ownership with countries like Pakistan, India and Sri Lanka having less than one-quarter ownership and relying on shared access (de Silva and Zainudeen 2008) but growing significantly by 2008 (Sivapragasam and Kang 2011). Finally, while one may have determined access or ownership ICT indicators or both, further understanding of the depth of usage has been the least understood, and today, it is asked in studies at varying degrees. 


\section{Usage}

There are many cases and researches around the usage of ICTs especially mobile phones in development but few attempt to measure ICTs among a measured lowincome population. Measuring ICTs can be understood for its usage to directly or indirectly improve the lives of the poor. Directly, we understand that direct cash transfers facilitated by ICTs could be an immediate approach to lift one out of income poverty. GiveDirectly is one institution providing direct mobile money transfers to a household phone, and the group's preliminary work finds the mobile money spent on basic food (GiveWell 2012). Indirectly, improving food security, financial inclusion and employment opportunities are three of the major research contributions available in describing ways in which the poor individuals or households use ICTs in attempt to improve their activities and livelihood. Citizens can help report on irregularities and therefore improve accountability on basic food distribution systems via SMS as is the case in India (Nagavarapu and Sekhri 2013). ICTs can also be used to improve rural livelihoods (which most likely occur in poor communities) through improved market access for produce as well as the lessening of food wastage (Grimshaw and Kala 2011). ICTs are observed as being used to help bring about changes to one's everyday life. These changes are then being attributed to the possible changes in one's level of poverty. In a review of mobile money or mFinance, new forms of banking facilities are now available which were not previously available to the poor, and in some cases, insufficient inputs (i.e. financial and literacy skills) are seen among the poor as well as some of their mixed perceptions around costs and risks (Leon et al. 2015 in Part II of this book). As for output, few studies have tried to understand cost savings and changes in business outputs among the poor (Leon et al. 2015). As for digital employment to the unemployed and the poor, we are also in the early days of this understanding. In terms of tackling poverty through improving income generation and work opportunities, groups such as Jana (or formerly txtEagle) and Samasource utilise microwork or the opportunity to offer small piecemeal work over the mobile phone to unemployed low-income personnel. These small earnings give even those most poor an opportunity to earn some meagre mobile phone credit which can help to diversify one's income earning portfolio. Despite these ICT studies in seeking its usage in improving the livelihoods and poverty levels of the poor, social ties and security or safety are seen as reasons for strongest usage (Galperin and Mariscal 2007). Awareness and usage of the Internet among the poor in selected countries in Asia were very low in 2008 (Zainudeen and Ratnadiwakara 2011). As seen above, many of the ICT usage demonstrations are found on small scale, without the use of rigorous methods of measuring changes particularly in indicators around poverty reduction (Kenny and Sandefur 2013). 


\section{Factors Affecting ICTs and Poverty: Affordability}

As part of usage, individuals or households commit to ICT usage through the purchase of ICT goods and services. Affordability of ICTs is another element which has come through within studies around poverty and ICTs. The concept is important particularly in ensuring a fair cost for communication which allows all citizens the opportunity to communicate. The three elements of access, ownership and usage all depend on whether ICTs are considered affordable among the poor. Barrantes and Galperin (2008) explore how far the poor were willing to spend by looking at an affordability threshold for the mobile phone (i.e. $5 \%$ of personal income of a basket of monthly mobile costs). Their multiple Latin America study found the poor had high basket monthly costs (e.g. 30-45\% in Brazil and Peru). These disturbingly high costs for mobile phone usage also showed lower mobile penetration in comparison to Latin American countries with lower monthly mobile costs (Barrantes and Galperin 2008). In one study of individuals in Africa, those individuals at the bottom $75 \%$ had a share of $10.9 \%$ of their monthly mobile expenditure in relation to income and those at the top $25 \%$ were spending $4.8 \%$ of their mobile expenditure (Gillwald and Stork 2008). In a later study in selected Asian countries, household data was compared and found that the poorest quintile exceeded $24 \%$ of their proportion spent towards mobile services over total monthly expenditures (Agüero et al. 2011) (see Table 2). As we look further down the quintiles, we also see that the spending proportion reduces; we see the richest quintile (top $20 \%$ ) spend far less than $10 \%$ on mobile services over total monthly expenditures.

From the demand of mobile phones, the researchers strongly suggest that communication functions as a necessity despite high costs. Further costs such as taxes on mobiles which increase mobile service expenditures may truly burden the most poor (Agüero et al. 2011). Even the most basic or everyday needs like food are in some cases being held back in order to afford the costs of mobile phone expenses (Diga 2007; Duncan 2013; infodev 2012a). In an economically depressed community in South Africa, the household respondents who earned a monthly income of between R300 to R5,000 (USD 37-USD 625) state that they on average use $26 \%$ of their income on cell phones (handsets and airtime) (Duncan 2013).

Table 2 Percentage of expenditure in mobile services in selected Asian countries by income quintiles $(\%)$

\begin{tabular}{l|l|l|l|l|l|l}
\hline Quintile & Bangladesh & Pakistan & India & Sri Lanka & Philippines & Thailand \\
\hline 1 (Bottom 20\%) & $\mathbf{2 9 . 7}$ & $\mathbf{4 5 . 8}$ & $\mathbf{2 4 . 3}$ & $\mathbf{2 7 . 0}$ & $\mathbf{5 7 . 0}$ & $\mathbf{2 4 . 4}$ \\
\hline 2 & 11.5 & 17.2 & 11.3 & 11.7 & 28.8 & 11.4 \\
\hline 3 & 7.8 & 9.9 & 8.4 & 6.5 & 18.4 & 7.3 \\
\hline 4 & 6.5 & 6.8 & 5.7 & 4.7 & 11.7 & 5.2 \\
\hline $5($ Top 20\%) & $\mathbf{3 . 8}$ & $\mathbf{5 . 1}$ & $\mathbf{4 . 4}$ & $\mathbf{3 . 1}$ & $\mathbf{6 . 3}$ & $\mathbf{3 . 7}$ \\
\hline
\end{tabular}

Source: Aguero et al. (2011) 
Majority of the study's respondents from this same township perceived both the mobile and the airtime to be expensive (Duncan 2013). One unanswered question is whether the high costs of ICTs are trapping people in poverty as suggested by Duncan (2013). This affordability question needs further exploration as regards to poverty and ICT.

As mentioned earlier, the IDI has been helpful in comparing ICT uptake through an index across countries; however, limitations are raised in trying to measure a subpopulation such as poor households. Barrantes (2007) attempts to further the study at a micro- or household level in calculating how many of the income poor were also failing to have ICTs in what she called "digital poverty". Digital poverty is defined as "the minimum ICT use and consumption levels, as well as income levels of the population necessary to demand ICT products" (Barrantes 2007: p. 33). In conceptualising digital poverty, the extreme digitally poor are households who are deficient of all forms of ICT connectivity and have little capability or mean to accept or deliver electronic messages or to participate actively (two-way interaction) with information. On the other hand, the digitally wealthy participate fully through electronic media both in receiving or sending information usually through the Internet (Barrantes 2007). All the various ICT access, ownership and usage indicators are combined together and are composed into the ICT household index. In an example of over 17,000 Peruvian households (in 2003), she identified $68 \%$ of the sample to be extremely digitally poor households. She then identifies the poor as those without sufficient income to cover the basic food basket of Peru, and this subpopulation was made up $17.59 \%$ of the selected sample. Those who were extremely poor were nearly all extremely digitally poor in 2003 . While this is an older study, it is one of the few trying to determine a composite indexed definition of ICT deprivation in relation to income poverty.

This early study was limited in household data around ICTs as each of the household members can have their own individual range of digital wealth or impoverishment. The main changes from 2003 were to remove household telecentre and computer usage and add more specific individual Internet usage such as whether someone was either ICT active or passive. Active Internet users are those defined as having the ability to have two-way interaction through the use of ICT transactions (Barrantes 2010). Thus, in this later study, the topology of digital poverty is updated to the following individual indicators in Table 3 (Barrantes 2010).

Table 3 Revised classification criteria according to their digital poverty level

\begin{tabular}{l|l}
\hline Digital poverty level & Indicators in survey \\
\hline Digitally wealthy & Telephone user, active Internet user \\
\hline Connected & Telephone user, passive Internet user \\
\hline Digitally poor & Telephone user, no Internet \\
\hline Extremely digitally poor & No telephone, no Internet \\
\hline
\end{tabular}

Source: Barrantes (2010), prepared by authors 
Table 4 Digital poverty status of households by financial poverty status and geolocation (\%)

\begin{tabular}{l|c|l|c|l}
\hline ICT & Not poor & Poor & Urban & Rural \\
\hline No ICT & 7.0 & 23.4 & 9.1 & 21.6 \\
\hline Digitally poor & 14.7 & 27.4 & 14.6 & 27.1 \\
\hline Connected & 50.8 & 38.0 & 48.8 & 40.1 \\
\hline Digitally wealthy & 27.5 & 11.3 & 27.5 & 11.3 \\
\hline$n=$ & & 1,473 & & 1,508 \\
\hline
\end{tabular}

Source: May (2012c)

When comparing the sample of 1,500 individual Peruvians of the digitally poor to the digitally wealthy, the demographic findings showed that the digitally poor were with lower annual incomes and lower levels of education and lived outside of Lima (urban capital). This study is also limited as a result of a small sample size, and it does not go further to identify the economically poor or nonpoor in this study and point out the subgroup's digital assets.

A digital poverty or ICT index has also been applied in East Africa (May 2012c). The features of May's (2012c) digital poverty are also different from both Barrantes' (2007, 2010) studies as May utilises a count in the number of ICT access or usage observations per capita. Taking a look at digital poverty from East Africa in 2007 and 2008, the economically poor (i.e. those below the absolute poverty line of USD 2.00 per capita per day) had certainly a larger proportion of the households without ICTs or being extremely digitally poor than those identified as not poor. Interestingly, there is nearly $15 \%$ of not poor who are also identified as digitally poor and in reverse around $11 \%$ of the poor who are digitally wealthy. One can also note similarities of the not poor percentages to that of urban geolocation and for the poor and rural (Table 4).

From the Barrantes $(2007,2010)$ and May (2012a, b, c) findings, those with few educated members in the household, lower-income levels and with few young people in the household may need further consideration in ways to increase their ICT participation. As a final note from the evolution of thinking around digital poverty is the distinguishing possibility of developing a digital poverty threshold. Barrantes takes a relativity stance by arguing that such a set target is impractical to monitor and review given the ever-changing ICT environment. The point is made that the sole monitoring of statistics on the insufficient ICT supply in poor areas will not be effective in moving people out of digital poverty.

All in all, there is no consistent rate within ICTD studies as to the poor's access, ownership and usage of ICTs. Furthermore, access and ownership concepts are further being solidified by the growing yet uneven rates of adoption by the poor in the various global subpopulations. ICT usage (including depth and quality of usage) among the poor, on the other hand, still appears up for debate and not well understood.

The possibilities of short- to long-term socio-economic changes or technological changes are vast within heterogeneous contexts and situations, and this particular review tries to delineate today's usage and ownership around ICT and 
controlling for certain factors, whether one can show ICTs' relationship to poverty reduction. Through this work, researchers reveal the heterogeneity of ICT demand by low-income individuals, households and communities. Nevertheless, across developing countries, we see growth of ownership and access to ICTs especially among poor countries and among the poorer population of those countries.

\section{Impact That Poverty Has on ICTs}

Some background papers have now covered the literature around ICT and poverty (Adeya 2002; Diga 2013; Spence and Smith 2009). One important feature to distinguish is the understanding of the causal inference of ICTs impact on poverty. One step is to first understand the direction in which we are examining impact. In one case, we can ask whether one's socio-economic status has an impact on one's ICT access, ownership or usage. In following up with the Barrantes and May research above, one can examine whether an individual's income level has a causal effect on ICT access. One theory can be that one with greater income can now afford say a mobile phone and thereby have a strong motivation to own and use various ICTs for their everyday use. Through her analysis, Barrantes (2010) confirms that the lower poverty level of the household, the improved likelihood for the household to be connected either via Internet access or mobile phone. As the data was only collected in 1 year, one is limited in the ability to measure impact or changes over time. Another attempt to test whether one's deprivation level had an effect on ICT access was done within poor communities in East Africa. While looking at all selected dimensions of poverty and ICT access, there was a positive and significant association (May 2012c). Upon closer observations, the findings showed better odds of ICT access when the household had at least one member with secondary education and living in urban areas (May 2012b). From the same 20072008 cross-section of this study, financial capital (through the per capita household expenditure indicator) relative to the absolute poverty line (USD 2.50 per person per day) appears to also be an important predictor of ICT access (May 2012c). There are still very few studies which have looked at this causal relationship among a larger aggregate population.

\section{Impact That ICTs Have on Poverty Reduction}

Improved reach of communication technology to the poor cannot be the only outcome in the debate around development. In looking at the other direction, research is observing the linkages of ICTs leading to poverty reduction. Toyama (2011) asks "how might mobile phones be exacerbating, rather than alleviating, poverty?" in his editorial. One theorises that through participating in ICT inclusive tasks, behaviour change occurs (whether it be obtaining income effectively or 
improving work processes efficiency), and through that, one hopes to find some level of longer-term impact on the individual's socio-economic status. An investment of time and effort in changing one's approach to work and generate a livelihood through the usage of ICTs could lead to an improvement of income and assets for individuals and their respective households. Ultimately, these improvements would see an individual or household move out of poverty. In looking at the previous pre2002 literature (Adeya 2002), the evidence was inconclusive and remained with uncertainty whether mobile phones and ICTs were causing more harm than good and vice versa.

Impact studies on poverty and ICTs while not abundant have sprouted in the last 10 years. One literature review (Duncombe 2011) examines studies on mobile phones, development and impact. Of the 18 studies he reviewed, four highlighted long-term impacts through mobile phones, while the others measured more short-term indicators. The impact studies reviewed by Duncombe had lowincome respondents or took place in low resourced communities, yet none of the reviewed studies in fact measured the changing levels of poverty among individuals or households.

One study which looks at multiple poverty dimensions, Aminuzzaman et al. (2003) mention that the ICTs measured in the study had less economic empowerment effects on users than compared to say transportation effects. Souter et al. (2005) highlight negative economic value of mobile phones by lower-income groups, while positive economic value was found with higher-income groups. Again this study did not necessarily address measurements of poverty level. Studies have become more sophisticated in trying to observe the changes over time of the same people or communities. Muto (2012) uses panel data to find Ugandan households more likely to leave rural areas for job-seeking migration when there is mobile phone ownership within the household.

One Tanzanian study conducts qualitative quasi-experimental work on small businesses using ICTs over time. The researchers monitored the changes of poverty over time among a randomly selected group of small business owners in two similar Tanzanian towns. One town's group of microbusinesses received a free mobile handset, mobile airtime (approximately USD 20 a month) and paid Internet email access of $1 \mathrm{~h}$ per week at an Internet café for 5 months (Mascarenhas 2014). The other town received none of these items. Both towns started with a similar poverty level of around $55 \%$ taken based on the income of the selected sample of businesses. After implementing the intervention, the one town with the ICT provisions saw poverty level drop to $16.1 \%$, while the other similar town without ICT provisions saw poverty level drop to $38.9 \%$ (Mascarenhas 2014). The study also examined multiple dimensions of poverty, with the treatment group (or the group with ICT provision) improving in five dimensions, and the control group without ICT provision only saw improvement in two dimensions. Within a short term, ICT usage had a clear effect on the small businesses compared to those who continued status quo.

The Tanzanian study above was part of the Poverty and Information and Communication Technology in Urban and Rural Eastern Africa (PICTURE Africa) project. 
Further applied statistical analysis by PICTURE Africa was completed to improve the impact understanding between poverty and ICTs. At the micro-level, the panel study measures the same household's multiple dimensions of poverty and ICTs over time. Households were randomly selected within a nationally representative sample of the poorest enumeration areas in four East African countries. The survey findings showed that the ICT index statistically causes change in per capita expenditure. Furthermore, that with every one unit increase of ICT access, one sees a $3.7 \%$ improvement in one's poverty status from 2007 to 2008 and 2010 in the four Eastern African countries (May et al. 2014). During the same period, the proportional expenditure change per capita in a household with ICTs was felt more strongly by the poorest than the nonpoor surveyed (May et al. 2014). The study thereby sees a slight movement of convergence between the poor and nonpoor based on the gains resulting from ICT access. In other words, the poverty level change is moving in a pro-poor direction. One must however be cautious of the results in that the gains made through the availability of ICTs to the very poor would only be seen in the medium term (6-10 years). This panel study represents a first in incorporating the poverty trends of looking at multiple dimensions of poverty and ICTs which can impact on the poor over time.

In the Duncombe (2011) review of mobile phone and impact, the one methodological gap was with the lack of participatory research methods. His concern was addressed through another applied participatory research case on ICT and changes in wellbeing among resource-poor communities, the community-based learning, ICTs and quality-of-life (CLIQ) project (Attwood 2013). The CLIQ project reviewed changes of self-perceived wellbeing of the same individuals in four poorer South African communities over time. This participatory research asked participants how their usage of computer training, free Internet and computer hours and goal setting affected their quality of life. The findings showed that in those participants who had high participation in the various intervention activities throughout the period and within telecentres with good functionality and process, one saw a greater response to quality-of-life change (Attwood et al. 2014). This unique study shows an innovative way of measuring ICT usage and wellbeing changes in a human-centred way. Furthermore, one takes this subjective status of participants, and it is the participants themselves who decide whether or not they have used the ICT tools to expand their choices and freedoms and thereby change their quality of life.

These quality-of-life impact findings as well as the PICTURE Africa findings are the first of its kind in exploring panel survey data and applied research analysis on the relationship between ICT and poverty. Both studies have given us a micro-level depiction of the nuanced mixed results of income, expenditure and self-perceived life impact changes over time. One can highlight that the findings are part of integrated Sen-inspired human development frameworks and assists in providing a more holistic understanding of the complexities around poverty reduction. This includes exploring the integration of ICT policy which supports human development where literature is limited (Diga et al. 2013). Furthermore, while these micro-level 
studies have certainly helped bring about ways to test an ICT composite index against poverty levels, these studies still need further refinement to include crucial indicators in the index such as less reported ICT skills. The ICT Development Index identifies ICT skills but only uses school enrolment and adult literacy as proxies to this ICT skills indicator. These findings as well as those which have been provided through descriptive findings above are part of the growing contributions of applied research and theory towards ICTs and poverty.

\section{Conclusion and Way Forward}

This study reveals the current progress within empirical description and analysis around measuring the nexus between ICTs and poverty. In looking at the literature, earlier reviews around the theory of ICT and development showed fairly simplified constructions of ICTs (either via access, ownership or usage) without well-measured indicators on the poor. Furthermore, earlier literature before 2002 concentrated on the macro-level of economic change, and less emphasis was placed on understanding the micro-level impact changes on poverty reduction. Research today acknowledges that ICTs could dually serve as tools for both economic development and poverty reduction.

Through this current review, one acknowledges that research in measuring poverty reduction at the micro-level has further developed in ICTD literature. Today, the variety of poverty measures being utilised by ICTD researchers appear to be aligned with the current concepts used by poverty experts. For example, both discipline streams are approaching poverty and ICT measurement in multiple dimensions and are attempting to analyse its transitions and impact over time. Despite this congruent nature of contemporary poverty theory and ICT research, there are still few studies within social welfare and poverty research trying to build on the measurement link between ICTs and poverty. With the importance of statistical analysis, less research has been done on ICTs and poverty (or wellbeing) through a participatory perspective. Participatory approaches and subjective wellbeing measures in ICT and poverty studies would add to the knowledge contribution in this field. The incorporation of the participatory methods which substantially involve the participants and where their aspirations and wellbeing are being asked is recommended. Applied techniques and refinement of indices for ICTs and the various poverty composite measures are also necessary to provide realistic recommendations to stakeholders on the future of ICT infrastructure or social policy development.

As a way forward, we are far from reaching the end on the war against poverty. Various approaches, interventions and participation would need to coordinate together to reach an end goal of improving the lives of the poor. Developing countries today have learned that national policy requires commitment to finding the ideal balance of inclusive growth—economic growth alongside social welfare 
policies-within one's limited national budget, and it is important to build on the strength of measurement in order to see the true nature of poverty. In reflecting on ICTs and poverty, Toyama (2011) however argues that communication technology will help to amplify the success or failure of existing institutional capacity towards development. Institutional competence, alongside varying costs and levels of training and capability will be elements which will make ICTs access and usage possible even for those of the underserved population.

While the ICTD community has produced evolving contributions towards understanding the connection between ICT and poverty, unfortunately less can be said for the social development community. The Millennium Development Goals (MDGs) reach their end in 2015, yet current suggestions around a next round of MDGs have little mention of ICTD in playing a contributory role or being in any way measured. Nevertheless, emerging research is observing some of the ICTD interventions in developing countries targeted at the goals and indicates some contributions towards poverty alleviation (Kaino 2013). More research work and advocacy for understanding the nexus between ICT and poverty will need to be raised in moving forward into the future. Furthermore, one must make note of global trends of economic instability and changing industrial development within a holistic development approach which may fundamentally change the way research is done around ICT and poverty.

The pronounced voice which comes from the south on ICT and poverty may suggest that there is great value in understanding the lived experience of using mobile phones in the everyday lives of people especially within resource-poor communities. Yet with all the various measures of ICTs, behaviour change and impact, the gap remains in further work in the south to understand this evolution of ICT and poverty over time.

While this study concentrated around poverty measurement, poverty cannot be viewed without looking at inequality. Massive global income disparities are still clearly found between countries and within countries. The improvement of work which distinguished whether there is a convergence of income and less inequality as a result of ICTs or vice versa would also be a move forward in ICT and poverty measurement research.

Today's soon to expire Millennium Development Goals are being re-evaluated within a time of global instability, pushing countries to make dramatic policy choices to that of the past. In other words, countries are taking recessionary initiatives which prioritise growth through economic policy. Finally, for the poor to truly benefit in wellbeing change, a country's economic growth strategy would likely need the support of complementary ICTs and other poverty reduction strategies through redistributed resources such as social welfare grants, health care, improved educational facilities etc. The fight to ensure that ICTs find their place within a balanced frame of inclusive growth will be the challenge moving forward during uncertain times.

Acknowledgements We would like to express our gratitude to those who reviewed and provided comments on this paper including: Roxana Barrantes, Arul Chib, Roger Harris, Mary Luz Feranil, Andrea Ordonez and Matias Dodel Schubert. 
Open Access This chapter is distributed under the terms of the Creative Commons Attribution Noncommercial License, which permits any noncommercial use, distribution, and reproduction in any medium, provided the original author(s) and source are credited.

\section{References}

Adeya, C. N. (2002). ICTs and poverty: A literature review. Ottawa: IDRC.

Agüero, A., de Silva, H., \& Kang, J. (2011). Bottom of the Pyramid expenditure patterns on mobile phone services in selected emerging Asian countries. Information Technologies and International Development, 7(3), 19-32.

Alkire, S., \& Santos, M. E. (2013). A multidimensional approach: Poverty measurement \& beyond. Social Indicators Research, 112(2), 239-257.

Aminuzzaman, S., Baldersheim, H., \& Jamil, I. (2003). Talking back! Empowerment and mobile phones in rural Bangladesh: A study of the village phone scheme of Grameen Bank. Contemporary South Asia, 12(3), 327-348. doi:10.1080/0958493032000175879.

Attwood, H. E. (2013). The influence of quality-of-life research on quality-of-life: CLIQ case studies from KwaZulu-Natal, south Africa. In M. J. Sirgy, R. Phillips, \& D. Rahtz (Eds.), Community quality-of-life indicators: Best cases VI (Vol. 4, pp. 1-18). Dordrecht: Springer.

Attwood, H., Diga, K., Braathen, E., \& May, J. (2013). Telecentre functionality in South Africa: Re-enabling the community ICT access environment. Journal of Community Informatics, 9(4).

Attwood, H., May, J., \& Diga, K. (2014). Chapter 8: The complexities of establishing causality between an ICT intervention and changes in quality-of-life: The case of CLIQ in South Africa. In E. O. Adera, T. M. Waema, J. May, O. Mascarenhas, \& K. Diga (Eds.), ICT pathways to poverty reduction: Empirical evidence from East and Southern Africa. Rugby: Practical Action Publishing.

Baron, L. F., \& Gomez, R. (2013). Relationships and connectedness: Weak ties that help social inclusion through public access computing. Information Technology for Development, 19(4), 271-295.

Barrantes, R. (2007). Analysis of ICT demand: What is digital poverty and how to measure It? In H. Galperin \& J. Mariscal (Eds.), Digital poverty: Latin American and Caribbean perspectives (The Regional Dialogue on the Information Society (REDIS-DIRSI), Eds., pp. 29-53). Ottawa: International Development Research Centre.

Barrantes, R. (2010, September). Digital poverty: An analytical framework. Paper presented at the Chronic Poverty Research Centre conference, University of Manchester, Manchester.

Barrantes, R., \& Galperin, H. (2008). Can the poor afford mobile telephony? Evidence from Latin America. Telecommunications Policy, 2008(32), 521-530.

Bhagwati, J., \& Panagariya, A. (2013). Why growth matters: How economic growth in India reduced poverty. New York: Public Affairs.

Byrne, D. M., Oliner, S. D., \& Sichel, D. E. (2013, March 27). Is the information technology revolution over? Available at SSRN: http://ssrn.com/abstract $=2240961$

Carter, M. R., \& Barrett, C. B. (2006). The economics of poverty traps and persistent poverty: An asset-based approach. The Journal of Development Studies, 42(2), 178-199.

de Silva, H., \& Zainudeen, A. (2008). Teleuse at the bottom of the pyramid: Beyond universal access. Telektronikk, 2(2008), 25-38.

Diga, K. (2007). Mobile cell phones and poverty reduction: Technology spending patterns and poverty level change among households in Uganda. Masters in Development Studies, University of KwaZulu-Natal, Durban.

Diga, K. (2013). Chapter 5: Access and usage of ICTs by the poor (part I). In L. Elder, H. Emdon, R. Fuchs, \& B. Petrazzini (Eds.), Connecting ICTs to development: The IDRC experience. London: Anthem Press/IDRC. 
Diga, K., Nwaiwu, F., \& Plantinga, P. (2013). ICT policy and poverty reduction in Africa. Info, $5(5), 114-127$.

Drèze, J., \& Sen, A. (2013). An uncertain glory: India and its contradictions. Princeton: Princeton University Press.

Duncan, J. (2013). Mobile network society? Affordability and mobile phone usage in Grahamstown East. Communicatio, 39(1), 35-52. doi:10.1080/02500167.2013.766224.

Duncombe, R. (2011). Researching impact of mobile phones for development: Concepts, methods and lessons for practice. Information Technology for Development, 17(4), 268-288. doi:10. $1080 / 02681102.2011 .561279$.

Galperin, H., \& Mariscal, J. (2007). Mobile opportunities: Poverty and mobile telephony in Latin American and the Caribbean. Lima: DIRSI, IDRC.

Gillwald, A., \& Stork, C. (2008). Towards evidence based ICT policy and regulation: ICT access and usage in Africa (ICT adoption and diffusion) (Vol. 1): Research ICT Africa and Johannesburg.

GiveWell. (2012, December). Cash transfers in the developing world. URL: http://www.givewell. org/international/technical/programs/cash-transfers/2012-version. Accessed Nov 2013.

Gomez, R. (2013). When you do not have a computer: Public-access computing in developing countries. Information Technology for Development, 20(3), 274-291.

Gordon, R. J. (2012). Is US economic growth over? Faltering innovation confronts the six headwinds (NBER Working Paper Series National Bureau of Economic Research). Cambridge. Retrieved from http://faculty-web.at.northwestern.edu/economics/gordon/Is \%20US\%20Economic\%20Growth\%20Over.pdf

Grimshaw, D. J., \& Kala, S. (2011). Strengthening rural livelihoods: The impact of information and communication technologies in Asia. Ottawa: IDRC.

Harttgen, K., \& Klasen, S. (2012). A household-based human development index. World Development, 40(5), 878-899. doi:http://dx.doi.org/10.1016/j.worlddev.2011.09.011.

Hulme, D. (2013). Poverty and development thinking: Synthesis or uneasy compromise? Manchester: University of Manchester.

infodev.(2012a). Mobile usage at the base of the Pyramid in Kenya. Washington, DC: The World Bank.

infodev. (2012b). Mobile usage at the base of the Pyramid in South Africa. Washington, DC: The World Bank.

ITU. (2011). World telecommunication/ICT indicators database. Retrieved from http://www.itu. int/ITU-D/ict/statistics/

ITU. (2012). Measuring the information society 2012. Geneva: International Telecommunications Union.

James, J. (n.d.). Product use and welfare: The case of mobile phones in Africa. Telematics and Informatics (0). doi:http://dx.doi.org/10.1016/j.tele.2013.08.007.

James, J., \& Versteeg, M. (2007). Mobile phones in Africa: How much do we really know? Social Indicators Research, 84(1), 117-126.

Kaino, L. M. (2013). Information and Communication Technology (ICT) and Attainment of the Millennium Development Goals (MDGs): The interdependence between MDGs' educational and socioeconomic goals. Journal of Communication, 4(1), 33-40.

Kenny, C., \& Sandefur, J. (2013, July/August). Can Silicon Valley save the world? Foreign Policy. http://foreignpolicy.com/2013/06/24/can-silicon-valley-save-the-world/

Leon, L., Rahim, F., \& Chib, A. (2015). The impact of mFinance initiatives in the global south: A review of the literature. In A. Chib, J. May, \& R. Barrantes (Eds.), Impact of information society research in the global south. Singapore: Springer.

Lipton, M. (1997). Editorial: Poverty-Are there holes in the consensus? World Development, 25(7), 1003-1007. doi:http://dx.doi.org/10.1016/S0305-750X(97)00031-4.

Mascarenhas, O. (2014). Impact of enhanced access to ICTs on small and micro enterprises in Tanzania. In E. O. Adera, T. M. Waema, J. May, O. Mascarenhas, \& K. Diga (Eds.), ICT pathways to poverty reduction: Empirical evidence from east and southern Africa. Rugby: Practical Action Publishing/IDRC. 
May, J. (2012a). Smoke and mirrors? The science of poverty measurement and its application. Development Southern Africa, 29(1), 63-75. doi:10.1080/0376835x.2012.645641.

May, J. (2012b). Tweeting out of poverty: Access to information and communication technologies as a pathway from poverty. Paper presented at the Towards Carnegie III: Strategies to Overcome Poverty \& Inequality, University of Cape Town. http://www.carnegie3.org.za/docs/papers/ 175_May_Tweeting\%20out\%20of\%20poverty\%20-\%20access\%20to\%20information\%20and $\% 20$ communication\%20technologies\%20as\%20a\%20pathway\%20from\%20poverty.pdf

May, J. D. (2012c). Digital and other poverties: Exploring the connection in four east African countries. Information Technologies and International Development, 8(2), 33-50.

May, J., Dutton, V., \& Munyakazi, L. (2014). Chapter 2: Information and communication technologies as a pathway from poverty: Evidence from East Africa. In E. O. Adera, T. M. Waema, J. May, O. Mascarenhas, \& K. Diga (Eds.), ICT pathways to poverty reduction: Empirical evidence from East and Southern Africa. Rugby: Practical Action Publishing/IDRC.

Meier, G. M. (1970). Leading issues in economic development (2nd ed.). Oxford: Oxford University Press.

Moser, C. O. N. (1998). The asset vulnerability framework: Reassessing urban poverty reduction strategies. World Development, 26(1), 1-19. doi:10.1016/s0305-750x(97)10015-8.

Muto, M. (2012). The impacts of mobile phones and personal networks on rural-to-urban migration: Evidence from Uganda. Journal of African Economies, 21(5), 787-807. doi:10.1093/jae/ejs009.

Nagavarapu, S., \& Sekhri, S. (2013). Role of ICT technologies in reforming TPDS: Information provision by SMS in Uttar Pradesh. Brown University. Paper under review.

Oliner, S. D., \& Sichel, D. E. (2000). The resurgence of growth in the late 1990s: Is information technology the story? The Journal of Economic Perspectives, 14(4), 3-22.

Rashid, A. T. (2011). A qualitative exploration of mobile phone use by non-owners in urban Bangladesh. Contemporary South Asia, 19(4), 395-408. doi:10.1080/09584935.2011.577206.

Ravallion, M. (2013). How long will it take to lift one billion people out of poverty? Washington, DC: The World Bank.

Rodrik, D. (2013). The past, present, and future of economic growth. Global Citizen Foundation.

Röller, L.-H., \& Waverman, L. (2001). Telecommunications infrastructure and economic development: A simultaneous approach. The American Economic Review, 91(4), 909-923. doi:10.2307/2677818.

Sen, A. (1999). Development as freedom. Oxford: Oxford University Press.

Sivapragasam, N., \& Kang, J. (2011). The future of the public payphone: Findings from a study on telecom use at the bottom of the Pyramid in South and Southeast Asia. International Technologies and International Development, 7(3), 33-44.

Soriano, C. R. R. (2007). Exploring the ICT and rural poverty reduction link: Community telecenters and rural livelihoods in Wu'an, China. The Electronic Journal of Information Systems in Developing Countries, 32.

Souter, D., Scott, D., Garforth, C., Jain, R., Mascarenhas, O., \& McKemey, K. (2005). The economic impact of telecommunications on rural livelihoods and poverty reduction. Reading: Gamos.

Spence, R., \& Smith, M. (2009). Information and communication technologies, human development, growth and poverty reduction: A background paper. Ottawa: IDRC.

Spence, R., \& Smith, M. (2010). ICT, development, and poverty reduction: Five emerging stories. Information Technologies and International Development, 6(SE (Special Edition 2010)), 11-17.

Stork, C., Calandro, E., \& Gillwald, A. N. (2013). Internet going mobile: Internet access and use in eleven African countries. Info, 5(5), 34-51.

Sumner, A. (2012). Where do the poor live? World Development, 40(5), 865-877. doi:http://dx. doi.org/10.1016/j.worlddev.2011.09.007.

Teltscher, S., \& Korka, D. (2005). Macroeconomic impacts. In G. Sciadas (Ed.), From the digital divide to digital opportunities: Measuring infostates for development (pp. 45-55). Montreal: Orbicom. 
Toyama, K. (2011). Technology as amplifier in international development. Paper presented at the proceedings of the 2011 iConference, Seattle.

Toyama, K. (2012). Can technology end poverty? Retrieved June 26, 2012, from http:// bostonreview.net/forum/can-technology-end-poverty/kentaro-toyama-responds

United Nations. (2013). A new global partnership: Eradicate poverty and transform economies through sustainable development. New York. Retrieved from http://www.un.org/sg/ management/pdf/HLP_P2015_Report.pdf

Waverman, L., Meschi, M., \& Fuss, M. (2005). The impact of telecoms on economic growth in developing countries. The Vodafone Policy Paper Series, 2(03), 10-24.

Wolfensohn, J. D. (2000, October 3). Poverty and development: The world development report 2000/2001. Paper presented at the conference on World Poverty and Development: A Challenge for the Private Sector, Amsterdam.

World Bank. (1980). WDR 1980: Poverty and human development. Washington, DC: World Bank Group.

World Bank. (1990). World development report 1990. Washington, DC: World Bank Group.

World Bank. (2001). World development report 2000/2001: Attacking poverty. Washington, DC: World Bank Group.

World Bank. (n.d.). World Bank archives - Alden Winship (“Tom”) Clausen. Retrieved June 26, 2013, from http://go.worldbank.org/DG1E29A900, Washington, DC.

Zainudeen, A., \& Ratnadiwakara, D. (2011). Are the poor stuck in voice? Conditions for adoption of more-than-voice mobile services. International Technologies and International Development, 7(3), 45-59. 